\title{
INDONESIAN TRADITIONAL ULAMA NOTIONS AGAINST WAHHABISM: A STUDY OF ABI AL-FADAL AL-SENORIY'S THOUGHT
}

\author{
MUHAMMAD ASIF* \\ Al-Anwar College for Islamic Studies, Rembang
}

\section{Abstract}

Studies of the early $19^{\text {th }}$ century on the classical literatures of traditional Indonesian Muslim scholars in response to Wahhabi developments have forgotten the important work of Kawākib al-Lam$m \bar{a} a b$ written by Abi al-Fadal al-Senoriy. This book emerged in the midst of a situation of massive expansion of Wahhabi teachings and of intense debate among modernist and traditional Muslim groups in Indonesia. This book also represents Nahdlatul Ulama's response towards Wahhabi teachings because the $23^{\text {rd }}$ Nahdlatul Ulama Conference in Solo in 1964 was recommended to be a referred book in pesantrens and other educational institutions of the Nahdlatul Ulama. Through descriptive-qualitative analysis, this article examines the thought of Abi al-Fadal al-Senoriy in the particular book. This article finds that Abi al-Fadal has carried out a critical study on Wahhabi teachings, which according to him opposes Sunni teachings for the Wahhabi teachings contradict some important foundation in the Abl al-Sunnab Islamic tradition in terms of theology, fiqh, and Sufism.

Kajian-kajian tentang literatur klasik awal abad ke-19 dari kalangan ulama tradisional Indonesia kaitannya dengan respon terhadap perkembangan Wahhabi telah melupakan satu karya penting Kawākib al-Lammā'ah yang ditulis Abi al-Fadal al-Senoriy. Ki-

\footnotetext{
* Corresponding author at: STAI Al-Anwar, Jl. Raya Semarang-Surabaya, Sarang, Rembang, Indonesia. E-mail: asifelfarizi@gmail.com
} 
tab ini muncul di tengah situasi mulai massifnya ekspansi ajaran Wahbabi dan intensnya perdebatan di antara kelompok muslim modernis dan tradisional di Indonesia. Kitab ini juga menjadi representasi sikap Nahdlatul Ulama terhadap ajaran Wabhabi karena pada Muktamar Nabdlatul Ulama ke-23 di Solo tahun 1964 direkomendasikan menjadi kitab rujukan di selurub pesantren dan lembaga pendidikan Nahdlatul Ulama. Melalui analisis deskriptif-kualitatif, artikel ini mengkaji pemikiran Abi al-Fadal al-Senoriy dalam kitab tersebut. Artikel ini menemukan bahwa Abi alFadal telah melakukan telaah kritis terhadap pemikiran Wabhabi, yang menurutnya tidak bisa dikategorikan sebagai Sunni karena bertentangan dengan fondasi penting dalam tradisi Islam Abl al-Sunnah, baik dalam hal teologi, fikih, maupun tasawuf.

Keywords: Abi al-Faḍal al-Senoriy; Al-Kawākib al-Lammā'ah; Indonesian traditional Ulama; Sunni Islam; Wahhabi teachings.

\section{Introduction}

Wahhabi became an Islamic purification movement that emerged in the $18^{\text {th }}$ century on the Arabian peninsula. It was founded by Muhammad bin Abdul Wahhab (1703-1792 AD). Abdul Wahhab's main idea according to el-Fadl is that Muslims have made the mistake in deviating the teachings of straight Islam, and only by returning to the only right path their deeds will be accepted by Allah. With this puritanical spirit, Abdul Wahhab wanted to liberate Islam from all destruction he believed had polluted Islam, including Sufism, doctrine of intercession, rationalism, Shia teachings, and practices that were considered heretics (El-Fadl 2005, 45).

At the same time, they encouraged ijtihad and condemned the practice of taqlìd and of following schools (madhābib). For Muhammad bin Abdul Wahhab, Muslim must choose between being a true believer or not at all. If Muslim explicitly or implic- 
itly performs an action that shows the impurity of his faith in God, he will be seen as an infidel (El-Fadl 2005).

Through the help and support of Ibn Saud, the ruler of al-Dir'aiyyah, Muhammad bin Abdul Wahhab would later succeed in spreading Wahhabi teachings to all areas in the Arabian peninsula. Algar noted that the history of the conquest of the Arabian peninsula by the alliance of the Wahhabi-Saudi group had left a trail of intolerance, the destruction of the tombs of prophet's companions and pious people, the massacre of hundreds of thousands of Muslims who were considered infidels and the impose of Wahhabi teachings on Muslims (Algar 2008).

The conquest of Mecca and Medina, as the holy cities and the centers of Islamic scholarship and intellectualism, which have been surviving up to now, in 1925 by the Wahhabi Saudi alliance got intellectual activities of Islam halted. It is noteworthy that such intellectual activities involved teachers and students from Asian countries, Malay-Indonesian, African and Indian (Algar 2008, 89). According to Hadler, Wahhabi is an ideology of "jihad" that encourages first Muslims in Southeast Asia through to do the Paderi war led by Imam Bonjol (Hadler 2008). In the Indonesian context, the emergence of the Nahdlatul Ulama (NU) organization in 1926 that accommodates traditional Muslims, by van Bruinessen, was considered a response to Wahhabi. According to him, theologically the aim of the establishment of NU was to defend practices that were hostile to Wahhabis such as pilgrimage to graves, taqlid, and țarīqah (Bruinessen 1994).

In the early development of Wahhabi, there was no intellectual work from Muslim scholars which critically responded Wahhabi thought and teachings. In this context, the presence of Abi al-Fadal is important ${ }^{2}$. He is one of the traditional In-

${ }^{2}$ Even the work of the Nahdlatul Ulama founder, KH. Hasyim Asy'ari, Risālah Abl al-Sunnah wa al-Jamā'ah seems likely that it does not respond to Wahhabism as such. 
donesian scholars who responded seriously Wahhabi teachings through his work al-Kawākib al-Lammā'ah. This book was recommended by the $23^{\text {rd }}$ NU Congress as the reference in all NU pesantrens and other educational institutions. Unfortunately, it seems that this figure and his works have not been any concern of scholars.

Martin van Bruinessen, who was considered successful in listing and mapping the books studied in Islamic boarding schools and traditional Muslim circles, also missed Abi al-Fadal in his studies (Bruinessen 1994). Even Zamakhsari Dhofier, an Indonesian Muslim intellectual with a traditional Muslim background, in his study of the pesantren tradition missed the figure. Instead, he referred to $\mathrm{KH}$. Bisri Mustofa, a contemporary ulama with Abi al-Fadal in his discussion of Ahl al-Sunnah wa al-Jama'ah (Dhofier 1980). Abi al-Faḍal wrote about the Ahl al-Sunnah wa al-Jama'ah earlier than Bisri Mustofa. The work of Abi al-Faḍal, Kawākib al-Lamma' $a h$, was recommended by NU-through the $23^{\text {rd }}$ NU Congress in Solo-as a book that must be read and taught in all pesantrens and educational institutions under $\mathrm{Nah}$ dlatul Ulama clerics. Both Martin and Dhofier did not even seem to mention at all about Abi al-Fadal. So far, there seems to be only one study of the Abi al-Fadal as the initial study of the text of the interpretation of Quran in terms of law verses (Asif and Arifin 2017).

This article discusses theological issues according to Abi alFaḍal bin Shaikh Abd al-Shakur al-Swedangi, particularly his criticism in his main work Kawākib al-Lammā'ah on the Wahhabi doctrine. Data was collected through in-depth interviews with the closest people to Abi al-Fadal, and studying the contents of his book.

\section{Abi al-Faḍal's Intellectual Genealogy}

His full name is Ahmad Abi al-Faḍal bin Shaikh Abd al-Shakur al-Swedangi, born in 1917 AD in Sedan, a small town 
in Rembang, Central Java. He was the last child of eight siblings: Muhammad Faḍil, Muhammad Faḍol (both died when they were children), Nafisah, Nafi'ah, Muniroh, Saidah, Abu alKhayr, and Abu al-Faḍal (Asif and Arifin 2017). As stated by Zamakhshari Dhofier, in a pesantren tradition, a Kyai will not gain any status and fame only because of himself, yet he becomes a Kyai because someone teaches him. Kyai typically represents a character of pesantren and its teacher where he studied. The validity and legality of the science must be proven through the chain of transmission which is usually well-structured and can be justified by other famous Kyais within the same period. That link or genealogy of a family is called sanad. Sanad itself has a standard, and this means that in one period there are certain scholars who are considered legitimate as such link, while others are considered null or doubtful (Dhofier 1980).

The intellectual genealogy of Abi al-Faḍal can be traced through his father who is his main teacher, Shaikh Abdus Shakur al-Swedangi. This information was confirmed by Abu al-Khair, his brother:

"He and I studied various branches of religious sciences from our father alone, not from someone else. He was always faster than me when memorizing and mastering various branches of Arabic, including Nahw, Sarf, Balaghah, Manțiq (logic), 'Arūdh. Qāfiyah, 'Ulūm al-Hadīth, Tafsir, and he memorized the Quran at the age of 18" (in Maimoen Zubair, n.d.).

Shaikh Abd al-Shakur al-Swedangi is the grandson of the Haji Saman-the Javanese term of Usman, an Arabic namethe first founder of an Islamic boarding school in Sarang, Rembang, in the early 1800s. The pesantren was then represented to Ghazali bin Lanah, and later became a number of pesantren with thousands of santri from various regions. By the people, Shaikh 
Abd al-Syakur was given the title "Shaikh al-Mashāyikh" or the teacher of the teachers (Maimoen Zubair, n.d.).

In 1296 H, Shaikh Abd al-Shakur traveled to Mecca, along with his best friend Umar Harun and his teacher Shaikh Kufrafi at-Tubani from Tuban. He spent at least for 5 years to study. Among his teachers was Sayyid Ahmad Zaini Dahlan, who was the Mufti of Mecca at the end of the reign of Usmaniyyah Daula in Turkey, Shaikh Madah, Sayyid Bakri as-Syațo the author of I'ānat al-Tālibinn, Shaikh Abd al-Hamid al-Sharwani, Sayyid Ahmad Zawawi, Shaikh Hasbullah bin Sulaiman al-Jawi, Muhammad Said bin Muhammad Bashil al-Hadrami (mufti of the Syafi'i school in Mecca in the early 1900s), Shaikh Umar bin Barakat al-Shami, and a charismatic cleric from Indonesia, Shaikh Nawawi al-Bantani (Maimoen Zubair, n.d.). The first name, Sayyid Zaini Dahlan (1816-1886 AD) was the mufti of Shafi' $i$ in Mecca in 1871 AD. He was the earliest figure to reject Wahhabi teachings, through his treatises (Algar, 2008: 135).

His another teacher was Kyai Hasyim Asy'ari, founder of the Nahdlatul Ulama. Although reported that Abi al-Faḍal studied in a short time with Kyai Hasyim, he received many chain transmissions of Muslim scholars from Kyai Hasyim, specifically regarding the narrators of Hadith. Some sources said that it was Kyai Hasyim as a teacher who requested Abi al-Fadal to study as a student. Kyai Hasyim wanted a son of his friend, Shaikh Abd al-Shakur to study with him. According to the source, Abi al-Faḍal was already pious when studying with Kyai Hasyim, so he did not need to take long to get knowledge chain transmission from Kyai Hasyim (an interview with Abdul Jalil and Minanur Rahman).

According to one of his students, once upon a time while teaching Abi al-Faḍal said that Kyai Hasyim gave all knowledge he had, saying, "ajaztuka jamī'a 'ulūmī" or "I have already giv- 
en you all my knowledge". One of the grandchildren of Kyai Hasyim, Ishom Hadziq was reported to have come to Senori to meet Abi al-Fadal to ask for the sanad of Kyai Hasyim (an interview with Mujamik, 2017).

During the data collection in the field, the author found the knowledge chain transmission of Șahịh al-Bukhārī of Abi alFaḍal from Kyai Hasyim Asy'ari. This sanad was obtained by Mujamik when reciting Sharh al-Sindī over Șahịh al-Bukhārī, with the editorial and series of sanad as follows: Ahmad Abu alFadal bin 'Abd al-Shakur al-Senoriy from Shaikh Muhammad Hasyim from his teacher, Shaikh Muhammad Mahfuz Termas al-Makki from his teacher Sayyid Abū Bakr al-Bakrī (d. 1310 H) from his teacher Sayyid Aḥmad Zaini Daḥlān (d. 1304 H) from his teacher Shaikh Uthmān al-Dimyāțī (d. $1181 \mathrm{H}$ ) from his teacher Shaikh Muhammad bin 'Ali bin Manșūr al-Shanwani from Shaikh 'İsā ibn Aḥmad al-Barāwī al-Shāfíi (d. $1182 \mathrm{H}$ ) from Shaikh Ahmad al-Dufrī (d. 1161 H) from Shaikh Sālim bin Abdillāh bin Sālim al-Bașrī (d. 1160 H) from his father, Shaikh Abdullah bin Sālim al-Bașrī al-Shāfi'i (d. 1134 H) from his teacher, Shaikh Muhammad bin Shaikh 'Alā'uddīn al-Bābilī al-Shāfi'i (d. 1077 H) from Abī al-Najā Sālim bin Muhammad al-Sanhūrī who narrated from Shaikh al-Hāfiz Muhammad bin Ahmad bin 'Ali al-Ghaițī (d. $981 \mathrm{H}$ ) from Shaikh al-Islām Abi Yahyā Zakariyyā al-Anșāri (d. 926 H) from al-Hāfiz Shihabuddīn Ahmad bin Hajar al-Asqalānī (w. 852 H) from Ibrāhīm bin Aḥmad alTanūkhi (d. 800 H) from Abī al-Abbās Aḥmad bin Abī Ṭālib (d. $733 \mathrm{H}$ ) from al-Husain bin al-Mubārak al-Zabīdi al-Bābali from Abī al-Waqt Abd al-Awwāl bin 'Īsa ibn Shu'aib al-Sajzī al-Harawi from Abī al-Hasan Abd al-Raḥmān bin Muẓaffar bin Dawūd al-Dawūdī from Abī Muhammad Abdillāh bin Aḥmad al-Hamwi al-Sarkhasī from Abī Abdillāh Muhammad bin Yūsuf bin Muẓaffar ibn Șāliḥ bin Bishr al-Firabri (d. 320 H) from 
the author, Abu Abdillāh Muhammad bin Ismā'īl al-Bukhārī bin Ibrāhīm bin al-Mughīrah ibn Bardazbah al-Ja'fī (d. 256 H).

Besides, the author gets sanad of Tafsir al-Jalālain of Abi alFadal that he received from Kyai Hasyim: Ahmad Abi al-Fadal (d. 1410 H/1990), from Hasyim Asy'ari (1871-1947 AD), from Mahfuz at-Tirmisi (1868-1919 M) from Sayyid Abu Bakr Bakri (d. 1892 AD), from Sayyid Zaini Dahlan (1816-1886 AD) from Shaikh Uthman ibn Hasan al-Dimyați, from Shaikh Muhammad bin Mansur al-Syinwani from Shaikh Isa bin Ahmad al-Barawi, from Shaikh Imam Ahmad al-Difari, from Shaikh Salim al-Bishri, from Shaikh Abdullah (father of Shaikh Salim al-Bishri), from Shaikh Muhammad ibn 'Alla' al-Din al-Babili, from Shaikh Abi al-Naja Salim al-Sanhuri, from Shaikh Muhammad ibn Abdurrahman al-Alqami, from Imam Jalal al-Din al-Suyuti. The lineage of the Sanad continues up to the author of the book Tafsir al-Jalālain, Jalāl al-Dīn al-Suyūtii. In a pesantren tradition, the genealogy of sanad is considerably valid if it can be traced up to the original author.

\section{Abi al-Fạ̣al's Works}

Among the works of the Abi al-Fadal that the author succeeded in finding were: in the field of monotheism: al-Kawākib al-Lammā'ah fì Tahquīq al-Musammā bi Abl al-Sunnab wa alJamā'ah, Sharh Kawākib al-Lammā'ah, al-Durr al-Farīd fī Sharh Nazm Jauhar al-Tawhìd, and Manzūmah al-Asmā' al-Husnā; the fields of Arabic: Tashīl al-Masālik, Kaifiyyah al-Ṭullāb, and Zubad Sharb al-Fiyyah, all of which were al-Fiyyah Ibn Malik's sages, Manzār al-Muwāfi who discussed the science of 'Aruḍ, and al-Jawāhir al-Saniyyah, about Șarf (morphology) in the form of naẓm, as well as Sharh Uqūd al-Jumān; Jurisprudence includes Iștilāh al-Fuqahā', Nazm Ashbah wa al-Nazāir, Nazm Kifāyah al-Țullāb fī al-Qawāid al-Fiqhiyyah, al-Wirdah al-Babiyyah fī al-Iștilāhāt al-Fiqhiyyah and Kashf al-Tabārīh fī Bayān Șalāh 
al-Tarāwiḥ; and the history of A bla al al-Musāmarah fì Hikāyat al-Auliyā' al-'Ashrah (Asif and Arifin 2017).

According to Abdul Jalil, Abi al-Faḍal wrote a commentary of al-Fiyyah, and a commentary Imam al-Suyūti in the field of Hadith, unfortunately, the author has yet found it. So, it is likely that the list of works will increase if any wants to trace from old generation of his santri. Unfortunately, there is no official data on the number of santris (and their names) that have studied with him.

Lately the author found two works of Abi al-Fadal, namely Tāj al-'Arūs li Tahdhīb al-Nufüs (still in the form of a manuscript) which was a translation of the work of Ibn Ațaillāh al-Sakandariy written on 10 Rabi' al-thāni 1361 H/25 April $1942 \mathrm{AD}$ and Kifāyah al-Țullāb which are summaries (in poetic form) of Ashbāh wa Nazāir by al-Suyūți. The second book was commented (Sharh) by Muhibbi Hamzawi (d.2007 M) who was also a student of Abi al-Fadial and was given the title Hidāyah al-Tullāb. Later the author also discovered other three works of Abi al-Fadal, which are still in the form of manuscripts, namely Sharh Uqūd al-Jumān ${ }^{3}$ and Tarjamah Qașidah al-Burdah, and Sharh Hisb al-Nașr by Imam Abu Hasan as-Sadhili.

Among Abi al-Faḍal's most widely read works, especially by pesantren, are al-Kawākib al-Lammā'ah and Aḅlā al-Musāmarah fì Hikāyah al-Auliyā' al-'Ashrah. The first book discusses Ahl al-Sunnah theology and criticism of Wahhabi teachings. According to Kyai Maemoen Zubeir, several works of Abi al-Fadal have been published in Turkey and a number of countries in the Middle East (interview with Kyai Maemoen Zubair, December 19, 2017).

If reviewing seriously the works of Abi al-Fadal, there are some of the works provided for pesantren's intellectual curricu-

${ }^{3}$ Sharb Uqū d al-Jumān discusses the science of Balaghah (Arabic literarture) written in a pegon accent, consisting of at least 19 small volumes. 
la. Some affirm the Ahl al-Sunnah ideology, and some also reflect his response to ideas and statements of Muslim reformists or purists as we can see from some of his works Kashf al-Tabārīh fī Bayān Șalāt al-Tarāwiḥ; al-Durr al-Farīd fī Sharb Nazm Jauhar al-Tauḅid (Al-Faḍal, n.d.) and al-Kawākib al-Lammā'ah. ${ }^{4}$

\section{Religious Polemic of Modernist and Traditional Groups in Indonesia}

According to Dobbin (2008), in Indonesia Wahhabi teachings were introduced by three people from Minangkabau who returned to Indonesia after their pilgrimage at Mecca in the end of 1803 AD. If previously Wahhabi teachings, though widely discussed in Mecca, were opposed by many. After the conquest of Mecca, Wahhabi teachings could be directly spread to the inhabitants of Mecca, including those pilgrims from Padang Indonesia. The three pilgrims from Padang had witnessed the Wahhabi occupation of Mecca, and were impressed with Wahhabi teachings. One of the most famous is Haji Miskin. Haji Miskin himself had previously been involved in the local awakening movement. They then slowly spread the teachings in the Minangkabau area. Because of the great zeal of Haji Miskin in spreading the movement, a local figure, Tuanku Mensiangan accepted the Wahhabi principle, "if all else fails, violence must be used to turn the country into Islamic and every village must be a pure Islamic society" (Dobbin 2008). Then between 1807-1832 the Wahhabi movement in Sumatra appeared in the form of the Paderi movement with two famous figures, Imam Bonjol and Tuanku Rao (Dobbin 2008, 257).

At the beginning of the $20^{\text {th }}$ century, several Islamic reform organizations emerged in Indonesia. They were inspired by the

${ }^{4}$ What was most clearly intended as a response to the reformist groups, especially Wahhabi was the first. 
Wahhabi movement, including Muhammadiyah which was founded by Ahmad Dahlan in 1912 AD and Islamic Union (Persis) which was founded by several people from Sumatra, including Haji Zamzam and Haji Muhammad Yunus. Previously, there were several movements and institutions of Islamic education in Sumatra that went on carrying out the spirit of Muslim renewal such as Sumatra Thawalib (Noer 1991).

According to Najib Burhani, Muhammadiyah began to be affected and later followed the Wahhabi purification model after the fall of Mecca and Medina in 1925 AD. There are at least factors that led to the case; first is the entry and development of Wahhabi ideology in Muhammadiyah, and the second is the involvement of figures from Padang who later influenced $\mathrm{Mu}-$ hammadiyah's ideology and their attitude towards local culture (Najib 2006).

The polemic about religious issues in Indonesia has received considerable attention from scholars. The polemic between modernist and traditional groups in the early $20^{\text {th }}$ century, for example, was described by Deliar Noer (1991) and Fauzan Saleh (2004). For instance, Noer said that the emergence of the puritanism movement in Indonesia, as well as in other countries originated from khilafiyyah (controversial/disputable) issues on jurisprudence and theology. In this case, the puritanism movement seeks to change the understanding of traditional groups. These include what they consider Muslim superstition and heresies (Noer 1991).

The issue that was debated according to Noer, concerns the problems of the concept of Ahl al-Sunnah, ijtihad and taqlid, Sufism and tariqa and the issue of heresy and khilafiyah issues such as pronunciation of "ușalli", reading qunut in subuh prayer, tarawih prayer and so on. This debate took place quite intensely and seized the attention of figures from modernist or traditional 
circles. In this polemic the modernist group is represented by Muhammadiyah and Persis while the traditional group is represented by Nahdlatul Ulama. Modernists tend to regard traditional group beliefs as the actors of shirk and heresies. Noer stated in his conclusion:

"Although this group claimed to be a follower of the generally Syafici school, they actually do not follow the teachings of the founder of the school directly, but the teachings of the imam who came later, often the ulama deviated from the teachings of the founder of the school. In Sufism, many of these groups fall into acts which lead to shirk, associating partners with God. They respect the sacred things, give offerings, hold slametan or kenduri as sadaqah (charity) to soul of the deceaseds, use amulets, talismans, or deter the rebels to protect themselves, all with the result of obscuring the notion of taubid" (Noer 1991, 320).

Modernists considered closer to Wahhabi often attack religious practices performed by traditionalists. While the traditionalists who feel that their religious activities are disturbed, do the counters. Theological debates took place intensely. This condition is straightforwardly described by Abi al-Fadal in his work, Kashf al-Tabārīh fī Bayān Salāt al-Tarāwiḅ: "what has suggested me to write this epistle is that I had heard some folk saying that the practice of performing tarawih 20 rakaat is bad innovation which came out of the Sunnah of the Prophet" (AlFaḍal, n.d.).

The debate between modernist and traditional groups continued until the 1970s. A modernist figure in Surakarta, Abdullah Thufail Saputra, a Javanese-Pakistani who in 1972 founded the Al-Quran Interpretation Majlis (MTA), violently attacked the practice of taqlid and schooling practiced by traditional groups. In two editions of the published brochure, he attacked 
the practice and categorized it as "worshipping other than Allah". He based his argument on surah al-Tawbah: 31,

"Based on the verses and narration mentioned above, it can be understood that what is considered as making religious leaders, clerics and pastors as God, is because all their speeches are always obeyed and imitated, without looking at or thinking about what talk they are in accordance with the basics of truth or not. In other words, the person who practices in religious matters means that he has worshiped other than Allah" (see Asif 2016).

Through al-Kawākib al-Lammā'ah and Sharb al-Kawākib, Abi al-Fadal explicitly counteracted the criticism of the modernist group. He analyzed important concepts debated by modernist groups such as bid'ah, taqlid or Sufism. He held that modernists have misunderstood those concepts. He also explicitly criticized Wahhabi as a source of modernists ideology (Al-Faḍal, n.d.).

\section{Al-Kawākib al-Lammā'ab: A Response to Wahhabi Ideology}

This book was completed on Monday $11^{\text {th }}$ of Jumadi alThāni in $1381 \mathrm{H}$. Abu Hamdān Abdul Jalīl (representative of the Katib 'Ām PBNU at that time) brought this book at the $23^{\text {rd }}$ NU Congress in Solo, Central Java. The congress participants welcomed it and decided to arrange a special team to do tașhì to the book. At the end of $1383 \mathrm{AH}$, or $1964 \mathrm{AD}$, in mid-May the tașhīh council was fixed in Denanyar, Jombang consisting of senior NU scholars such as Kyai Bisri Syamsuri, Kyai Adlan Ali, Shaikh Khalil, Shaikh Mansur Anur, who came originally from Jombang, and Kyai Turaikhan Adjhuri (Kudus), Shaikh Abdul Majid (Palembang), Kyai Raden Muhammad Karim (Solo), Shaikh Muhammad al-Baqir Marzuki (Jakarta), Kyai Abu Khamdan Abdul Jalil, and Kyai Nur Jalil (Martapura, South Kalimantan). They all came to discuss the book (Al-Fadal, n.d.). The book was recommended to be taught and read by all 
pesantren, as well as schools under NU. While the commentary of the book was finished in writing on Sunday, 28 Muharram 1385 Hijri, it means 4 years after the writing of the book of matan (the text of the original book).

This book seems to be the most detailed book on the concepts of Ahl al-Sunnah wa al-Jamā'ah written by scholars from a traditional Indonesian Muslim circle. At least only Risālah Abl al-Sunnah wa al-Jamā'ah was written by the founder of NU, Kyai Hasyim Asy'ari and Nușūs al-Islamiyyah Radd ala Madhhab Wahhābiyyah by Kyai Muhammad Faqih Maskumambang, Gresik (Faqih 2005), Rais Akbar's representative from Kyai Hasyim Asy'ari who preceded al-Kawākib al-Lammā'ah. However, the first book needs further explanation, and less detailed.

While the second book is a more sharply counter to Wahhabi. This second book was first published in Egypt in 1922 and distributed in other Middle Eastern countries. After al-Kawākib al-Lammā'ah, several other works were written such as Risālah Ahl al-Sunnah wa al-Jama'āh written by the Kyai Bisri Mustofa, Hujjah Ahl al-Sunnah wa al-Jama'āh by Kyai Ali Maksum (Yogyakarta ), written in 1983 (Maksum, n.d.), by Kyai Misbach Mustofa, brother of the Kyai Bisri Mustofa, entitled Anda Ahlussunnah, Anda Bermadzhab? (Mustofa 2006). Outside NU, there is I'tiqad Ablussunnah Wal Jama'ah (first published in 1969) by Ustadz Sirojudin Abbas, a figure from the Persatuan Tarbiyah Islamiyah (PERTI), a traditional Muslim organization Syafi'i, based in Medan, North Sumatra. This latest work is widely circulated among Malay Muslim communities, such as Malaysia, Brunei, Singapore, and Pattani, Southern Thailand (Abbas 2008).

The book al-Kawākib discusses the concept of Ahl al-Sunnah, which at that time was a serious debate among Indonesian Muslims. This book is also a direct counter to the Wahhabi doctrine and movement which at that time began to be disseminated in 
Indonesia. The full title of this book is al-Kawākib al-Lammā'ah fì Tahqīq al-Musammā bi al-Sunnah wa al-Jamāah. The word "al-Kawākib" (Arabic) is a plural form of the word kawkab that means star, while "al-Lammā'ah" means to shine brightly. This name is most likely inspired by the Prophet's Hadith stating that aṣhābi ka al-nujūm ... 'my companions are like stars'. In accordance with its title al-Kawākib al-Lammā'ah, Abi al-Faḍal acknowledges that this book was written because at that time groups emerged claiming to be Ahl al-Sunnah but they were not.

Abi al-Fadal began his explanation by mapping the development of Islamic theology from the time of the Prophet $\mathrm{Mu}$ hammad saw. to the emergence of Wahhabi figure Muhammad bin Abdul Wahhab who came from Nejad, Saudi Arabia. He explained that in the era of the Prophet, among Muslims there was no theological debate that led to division and group fanaticism because all the problems could be addressed directly to the prophet. According to him, al-Quran praises this. This condition continued until the second caliph, Umar ibn Khatțab. The dispute began after the killing of the $3^{\text {rd }}$ caliph, Uthman bin Affan. That was the beginning of a dispute in the history of Islam which then gave rise to many different or theological groups including Khawarij and Syi'ah. Each claims the truth of their group city. They both were divided into groups.

At the end of tabi'in (generation after the prophet companions) time, the emergence of a group called the $\mathrm{Mu}$ 'tazilah emphasized reason in understanding revelation, which was pioneered by Washil bin Atho' (80-131 H). Among Washil's students was Hasan Bașri, the cleric who would later be considered the father of the Sunni group. Disagreeing with his teacher who was considered to want to subdue revelation to reason, and put aside the Sunnah of the Prophet, Hasan Basri then left the Washil group. Hasan Bașri then counteracted the Mu'tazilites. In subsequent debates, the term Ahl al-Sunnah or firqah naji- 
yyah (the safe group) emerged as a group of survivors promised by the Hadith of the Prophet (Al-Fadal, n.d.).

Ahl al-Sunnah wa al-Jama'ah appears as an expression for people who hold fast unto the Sunnah of the Prophet, and the way of the Companions both in terms of 'aqidah, worship and morality as well as a counter to existing ideologies. The appearance of the name Abu Hasan Asy'ari and Imam Maturidi was later considered by Abi al-Fadal to successfully resolve the debate at that time. Abu Hasan Asy'ari (w. $324 \mathrm{H}$ ) and Imam Maturidi $(\mathrm{d} .333 \mathrm{H})$ argue that to understand the Quran it is necessary to present the prophetic Hadith, as well as the explanations and practices of the companions of the Prophet. They formulated their theological views. While in the field of figh, four schools were formulated by Imam Abu Hanifah, Imam Malik, Imam Shafi'i, and Imam Ahmad Bin Hanbal (Al-Faḍal, n.d.).

Linguistically, Ahl al-Sunnah wa al-Jamā'ah according to Abi al-Fadal derives from two words, namely the word sunnab (Arabic word) which means: al-wajh (face), al-jabhah (forehead), and al-sirah (road, history). The word al-Sunnah is defined terminologically into; first; sirah (history) and tarīqah (path) taken by the Prophet, second; something that if done will lead to a reward and if left will have no impact of punishment (sinless). While the word al-jamāah means referring to the number corresponding to 3 (three) or more. al-jama $\bar{a}$ ah means: first, some being bound within a congregational prayer with other people, second; gathering of Muslims under the oath of a priest (Al-Fadal, n.d., 30).

But any term according to him has to be returned to 'urf (habits, customs) where the term is used. He then defined:

"Know that the term Ahl al-Sunnah wa al-Jamā'ah is a form of term that is habitually attached to four groups, namely muhaddithīn (hadith expert), șūfiyah (the Sufis), and Ash'āri theology and Matūridi, because they are believed to be the ones who hold fast to the Sunnah and the 
țariqah (path) of the prophet, and the way of the companions and tabi 'in" (Al-Faḍal, n.d.).

In practice, according to Abi al-Fadal, adherents of Ahl al-Sunnah are those who follow the understanding of the four schools (Imam Hanafi, Imam Maliki, Imam Shafi'i, and Imam Ahmad bin Hambal) in the field of Jurisprudence or law, following the Imam al-Maturidi Hanafi School of Religion) and Imam Abu Hasan al-Ash'ari (adherents of the Madhhab Shafi'i) in the matters of kalam (tawhid) or theology. Because, in the course of its history, according to Abi al-Fadal, they were recognized as historical figures who succeeded in holding fast to the prophetic Sunnah and friends. They are also the ones who formulate laws and teachings that are in line with the Sunnah of the Prophet and the consensus of the companions and succeed in preserving them from the onslaught of the groups which are considered to intersect the teachings of Ahl al-Sunnah Islam.

In the modern age, the emergence of Muhammad bin Abdul Wahhab (1703-1791 AD), the founder of the Wahhabi sect was taken into account by Abi al-Fadal as the beginning of a sharp dispute among Muslims. Abdul Wahhab ponders Muslims to have made a mistake by committing irregularities towards the straight path, and only by returning to the right path will they be accepted and received from Allah (El-Fadl 2005, 45).

According to Algar, Wahhabi teachings are centered on three taubid divisions: tawhìd al-rubbübiyyah, the recognition that only Allah swt. has the nature of Rabb (God), the ruler and creator of the world, which enlivens and revives; tawhid al-asmā' wa al-șifat, only justifies the names and attributes of God referred to in the Qur'an, without being accompanied by ta'wìl. It is not permitted to apply those names to anyone other than God; tawhīd al-ibādah which requires all worship to be addressed only to Allah swt. The last tawhìd form is the most im- 
portant part of Wahhabi teachings. This is what can distinguish clearly between Islam and polytheism. In this case, a Muslim is not allowed to involve another party or go through an intermediary in worship, for example praying by using intermediary of the prophet Muhammad or pious people. This is called tawassul and is considered against tawhid (Algar, 2008; 70-71).

If non-Muslim observers opine that Wahhabism as an extreme and uncompromising form of Sunni Islam, Abi al-Fadal does not agree with such opinion. Algar, also agreed with the view of Abi al-Fadal. He rejects Wahhabi as a part of Sunni Islam. He argued that from the beginning the Sunni scholars had observed that Wahhabis did not belong to the Ahl al-Sunnah. This is because almost all practice and tradition condemned by Wahhabis historically has become an integral part of Sunni Islam. That Wahhabi is considered a Sunni indicates that the Sunni term has been given a very loose meaning, as merely the recognition of the first four caliphs. Likewise, according to him, the term Sunni which has been developing is no more than meaning "non-Shia" (Algar, 2008: 29-30). Khaled Abou el-Fadl does not only reject Wahhabi as a Sunni but also questions the orthodoxy of Wahhabi teaching (El-Fadl 2005).

Abi al-Fadal noted that there are several doctrines regarded as the main characteristics of Wahhabi teachings and distinguish them from Sunni groups (Al-Faḍal, n.d., 34). First, determining the physical faces, hands, direction, and physical activities such as going down, and ascending for Allah swt. This doctrine is often known as tajsim or anthropomorphism. Muhammad bin Abdul Wahab considers that God has a physical face (Wahhab 2007, 9) resides in the Throne 'Arsh, above the $7^{\text {th }}$ sky whereas, the Quran says laisa kamithlihi shai'un, nothing similar to Him. Second, rejecting reason ' $a q l$ in the matter of creed/aqidah. Third, ignoring and denying the consensus of the Prophet's companions and denying qiy $\bar{a} s$ as a source of Islamic law. Four, 
takfìr doctrines, claiming Muslims infidels who have different understandings with them. Wahhabi forbids tawassul (praying through intermediaries) the prophet and other devout people/ saints, even accuses it of a shirk. Likewise, they prohibit a grave visitation. In his work, Kitab al-Tawhìd, which later became the main reference of the Wahhabi group, Muhammad bin Abdul Wahhab made the chapter "being exaggerated with the graves of pious people means that those Muslims have made other worshiped idols, other than Allah swt. that includes a prayer in the tomb of a pious person" (Wahhab 2007, 41).

Wahhabi also strongly forbid taqlìd to the mujtahid ulama, and categorize the perpetrators as infidels. Regarding this takfir doctrine, Abi al-Faḍal did a counter by saying:

"The doctrine has easily claimed infidels addressed to those who pray to Allah through the intercession of the Prophet, the prophets, saints and pious people ... Muhammad bin Abdul Wahhab and his followers claimed infidelity of people practicing tawassul with prophets, saints, pious people, to fulfill their needs and to express their inconvenience as a form of shirk against tauhid ilähiyyah and rubbübiyyah by using the arguments of the verses which are actually related to the infidels (not Muslims). Yet, they then forced to apply the verses for the Muslims who practice tawassul". The Prophet once said in a Hadith "whoever accuses his Muslim brother of being an infidel, the accusation indeed returns to him alone"(AlFaḍal, n.d., 69-70).

Furthermore, Abi al-Fadal criticized the group for claiming themselves to be ahl al-Hadith and refused to adhere the four schools of Islam. According to him, the term abl al-Hadith by Wahhabi has been misused and excluded from its original definition used by the ahl al-Hadith (muhaddith). He quotes the definition of al-Subki that what is called abl al-Hadith is a person who masters isnād, 'ilal (a disease or note in a Hadith) and 
has knowledge of asmā' al-rijāl (narrators of Hadith), and sanad al-'àlì wa al-nāzil's.

In addition, according to him, ahl al-Hadith also has to memorize Hadith in abundant amounts and has at least performed $\operatorname{sim}^{-} i$ (hearing directly from the Hadith teacher when reciting Hadith) kutub al-sittah (the six referential books of Hadith), Musnad Ahmad, Sunan al-Baihāqi, as well as Mu'jam al-Ṭabrāni (Al-Faḍal, n.d.). That is the lowest level for abl alHadìth. He said, "it is not allowed to name ahl al-Hadith for groups that do not meet these criteria, because the term has become an embedded science attached to them. Similarly, in terms of not being allowed to refer to every human being by the term " "abdullāb", even though in reality they are servants of Allah swt."(Al-Fadal, n.d.).

Abi al-Fadal criticized the Wahhabi call upon every Muslim to do ijtihād by referring directly to the Quran of Hadith and criticizing taqlìd. In his opinion, to be able to achieve ijtihād level, Muslim must fulfill various requirements: knowing the aqli arguments and taklif, mastering Arabic in depth with various branches of knowledge, mastering ușul al-fiqh, knowing ijma', mastering 'ulum al-Quran, mastering Hadith science until someone reaches a level of being abl al-Hadith, and knowing sirah (history) of the prophet's companions (Al-Fadal, n.d., 43-44). People who are not able to carry out ijtihād are obliged to follow the Imams of the four schools.

By quoting Ibn Șalah, he divides mujtahid (those who strives to do ijtihad) into two: mustaqil and ghairu mustaqil. The former (independent) is a mujtahid who discovers theories and methods for doing ijtihad like the Imams of the four schools.

${ }^{5}$ In the hadith science sanad al-'ālì means a hadith that its transmission narrators (rāwi isnād) is less than three levels (tabaqāt). While al-nāzil means a hadith that its transmission narrators ( $r \bar{a} w i$ isna $\bar{a})$ is is numerous and more than three levels. 
This category, according to Ibn Salah, no longer appears in the days after those Imams. Whereas ghairu mustaqil is a mujtahid who does ijtihad by using ijtihad theories and methods formulated by the founders of the schools. They are people who fulfill the requirements of ijtihad but they do ijtihad in order to develop the schools of its founders (Al-Fadal, n.d.).

In Abi al-Fadal's point of view, since Wahhabi's insistence to do ijtihad, they have legalized some unlawful things. Similarly, leaving something that is actually obligatory and prohibiting something religiously suggested (Al-Fadal, n.d.). For him, mistakes in doing ijtihad-for people who are not qualified with the criteria-will steer to misunderstanding religious texts. Sufism condemned by Wahhabi for Abi al-Fadal is an integral part of Islam which is a characteristic of Ahl al-Sunnah. In this case, Abi al-Fadal gave an important account of Sufism:

"My brothers should know that Sufism is a kind of knowledge that shines in the hearts of the God's saints who are illuminated by surprising achievements as a result of practicing the Quran and Sunnah sincerely. It then gives birth to knowledge, morality, and sirr (revealed secrets) and the essence that cannot be explained orally ..." (Al-Faḍal, n.d., 37).

Nonetheless, it has for him become an agreement of ulama' that people may take the path of Sufism after mastering and practicing Sharia, mastering the Quranic sciences such as ' $\bar{a} m$ and $k h \bar{a} s, n \bar{a} s i k h$ and mansūkh and mastering Arabic in depth. He quoted Al-Junaid who held that "People who do not memorize the Quran and do not write Hadith should not be followed regarding the path of Sufism, because our knowledge (tașawuf) is based on the Quran and Hadith". The scholars of Sufism according to him are people who memorized the Quran and are the Hadith experts. He criticized Wahhabis who generalize that all forms and practices of Sufism oppose Sharia and consider it 
heretical. For him, their generalization has no basic argument and he was convinced that Wahhabi misunderstood Sufism (AlFaḍal, n.d.).

Broadly speaking, according to Abi al-Fadal, Wahhabi cannot be categorized into Ahl Al-Sunnah for three main reasons: rejecting authoritative fiqh schools though they cannot be recognized as ahl al-Hadith; condemning Sufism; and being contrary to Ash'ariy and Maturidiy theology. These three things in his idea are inseparable from each other in Ahl Al-Sunnah theology. In this case, Abi al-Fadal gave an example that Imam Ash'ariy was a follower of the Shafi'i school. While Imam Maturidi was a follower of the Hanafi school. Correspondingly, the jurists from the Maliki school all adhered to the Ash'ary theology, as did the Hambali school of jurisprudence. All jurists in four schools (Hanafi, Maliki, Syafi'i and Hambali) adhere to the theology of Ash'ariyah and Maturidiyah in matters of tawhid (Al-Faḍal, n.d.).

The criticism of Abi al-Fadal to Wahhabi can be regarded as a remarkable attention of an Indonesian traditional ulama for the massive development of Wahhabi preaching and their intolerant attitude towards different Muslim groups at that time. Nevertheless, Abi al-Faḍal tends to generalize modernist-puritanist groups in Indonesia as part of Wahhabi. He even categorized Muhammadiyah as Wahhabi. A contemporary Muslim scholar, Khaled Abou El-Fadl has distinguished between Wahhabism and Salafism. Wahhabism based its doctrinal formula on Muhammad bin Abdul Wahhab.

While Salafism refers to Ibn Taymiyyah, al-Syaukani, and in the modern century it was renewed by Jamaluddin Al-Afghani (d. 1897 AD), Muhammad Abduh (d. 1905 AD), and Rashid Riḍa (d. 1935 AD) and Jalāl al-San'ani (w.1810 AD). Both Wahhabi and Salafi both have "a big project" in purifying Islam from various forms of heresy and religious innovation. In contrast to 
Wahhabism, Salafism does not hate Sufism, nor does it actively oppose the tradition of following madhāhib (schools) (El-Fadl 2005). Wahhabism tends to close away from secular knowledge originating from the West, while Salafism even tries to introduce a modern education system that seeks to integrate religion and secular science (Rusli 2014). However, Noorhaidi Hasan, argued that Wahhabism had a major influence on Salafism. The development of Salafi preaching in modern Indonesia has been greatly influenced by Wahhabis and received full support from the Saudis (Hasan 2011).

\section{Conclusion}

Based on the analysis, it can be concluded that al-Kawākib al-Lammáa $a$ h emerged in the midst of the massive expansion of Wahhabi teachings and the intense debate among modernist Muslim groups dealing with traditional Muslims in Indonesia. Through this work, Abi al-Faḍal made his critical response to Wahhabi by concluding that Wahhabi teachings are not included in Ahl al-Sunnah (Sunni), because of their strong rejection and criticism of the main building of Sunni Islam in the fields of theology, fiqh, and Sufism. Indeed, Abi al-Fadal actually questioned the basic orthodoxy of their teaching since they have claimed to be the purest and have the most Islamic version based on the Quran and Hadith.

\section{Bibliography}

Abbas, Sirajudin. 2008. I'tiqad Ablussunnah Wal Jama'ah. Jakarta Selatan: Pustaka Tarbiyah Baru.

Al-Faḍal, Abi. n.d. Al-Durr Al-Farīd Fì Sharh Nażm Jauhar AlTawhīd. Tuban: Majlis Nashr Muallafāt Shaikh Ahmad Abi al-Faḍal.

\section{- n.d. Al-Kawākib Al-Lammā'ah F̄̄ Tahqūq Al-Musammā Bi Abli Al-Sunnah Wa Al-Jamāàh. Kudus: Kereta Putera.}


- n.d. Kashf Al-Tabārīh Fì Bayān Salāt Al-Tarāwih.

-n.d. Sharb Al-Kawākib Al-Lammä’ah.

Algar, Hamid. 2008. Wahhabisme Sebuah Tinjauan Kritis. Jakarta: Paramadina.

Asif, Muhammad. 2016. Majlis Tafsir Al-Qur'an (MTA): Dinamika, Doktrin dan Pencarian Wacana. Malang: Madza Publishing.

Asif, Muhammad, and Mochammad Arifin. 2017. "Tafsir Aḥkām Pertama Dari Pesantren: Telaah Awal Atas Tafsīr Ayāt Al-Aḥkām Min Al-Qur'ān Al-Karīm Karya Abi AlFaḍal Al-Senoriy." Subuf Jurnal Pengkajian Al-Qur'an dan Budaya. doi:10.22548/SHF.V10I2.194.

Bruinessen, Martin Van. 1994. "Pesantren and Kitab Kuning: Maintenance and Continuation of a Tradition of Religious Learning." In Texts from the Islands Oral and Written Traditions of Indonesia and the Malay World, edited by Wolfgang Marschall, 121-45. Berne: University of Berne.

Dhofier, Zamakhsyari. 1980. "The Pesantren Tradition: A Study of the Role of the Kyai in Maintenance the Traditional Ideology of Islam in Java." Australian National University. doi:10.1063/1.3095680.

Dobbin, Cristine. 2008. Gejolak Ekonomi, Kebangkitan Islam, dan Gerakan Padri Minangkabau 1784-1847. Depok: Komunitas Bambu.

El-Fadl, Khaled Abou. 2005. The Great Theft Wrestling Islam from the Extremists. San Franscisco: HarperOne.

Faqih, Muhammad. 2005. Menolak Wahhabi. Jakarta: Shahifa.

Hadler, Jeffrey. 2008. "A Historiography of Violence and the Secular State in Indonesia: Tuanku Imam Bondjol and the Uses of History." The Journal of Asian Studies 67 (03). doi:10.1017/S0021911808001228. 
Hasan, Noorhaidi. 2011. "Salafi Madrasas and Islamic Radicalism in Post-New Order Indonesia." In Islamic Studies and Islamic Education in Contemprory Southeast Asia, edited by Ahmad Kamaruzzaman Bustaman Jory Patrick and, 93. Kuala lumpur: Yayasan Ilmuwan.

Interview with Abdul Jalil, Son of Abi al-Fadal, Tuban, 5 September 2010 and 21 Febuary 2011.

Interview with Kyai Maemoen Zubeir, Pondok Pesantren Al-Anwar, Sarang, Rembang, 19 December 2017.

Interview with Minanur Rahman, santri and son-in-law of Abi al-Faḍal, Sedan, Rembang September 2010, 18 July 2014, and February 2017.

Interview with Mujami', santri of Abi al-Faḍal, Tuban, December 2016 and 22 November 2017.

Interview with Zainul Milal Bizawie, son of Kyai Muhibbi Hamzawi, 30 May 2017.

Maimoen Zubair. n.d. Tarājim Mashāyikh Al-Ma'āhid Al-Diniyyah Bi Sarang Al-Qudamā'. Rembang: Ponpes Al-Anwar Sarang.

Maksum, Ali. n.d. Hujjah Aḅl Sunnah Wa Al-Jamāa'ah. Pekalongan: Ibnu Masyhadi.

Mustofa, Misbach. 2006. Anda Ablussunnah? Anda Bermadzhab? Tuban: Al-Misbah.

Najib, Burhani Ahmad. 2006. "The Ideological Shift of $\mathrm{Mu}-$ hammadiyah from Cultural into Puritanical Tendency in 1930s." Jurnal Masyarakat Dan Budaya 8 (1): 1-22.

Noer, Deliar. 1991. Gerakan Modern Islam Di Indonesia 19001942. Jakarta: LP3ES.

Rusli. 2014. "Indonesian Salafism on Jihad and Suicide Bombings." Journal of Indonesian Islam 08 (01): 91-111. doi:10.15642/JIIS.2014.8.1.91-111. 


\section{MUHAMMAD ASIF}

Saleh, Fauzan. 2004. Teologi Pembaharuan: Pergeseran Wacana Islam Sunni di Indonesia Abad XX. Jakarta: Serambi.

Wahhab, Muhammad bin Abdul. 2007. Kitāb Al-Tawhīd. Kairo: Maktabah al-Hadyu al-Muhammadiy. 